\title{
Gay Liberation Front and Radical Drag, London 1970s
}

\author{
Shaun Cole
}

The film Loverboy: Charles Jeffrey Takes New York, ${ }^{1}$ was screened at a recent symposium on the "Future of Subcultures" hosted by London College of Fashion and $i-D$ magazine. The film, which follows London-based designer and queer club host Charles Jeffrey trip to New York to show his work and participate in the new radical queer club scene, turned my mind to the genderfuck practices and radical drag of members of the London Gay Liberation Front (GLF) in the early 1970s. The play with gendered and sexual identity manifesting itself through dress at Jeffrey's London club night "Loverboy" (as well as other London club nights and through his "Loverboy" design collective) and at New York's "Battle Hymn" club where, in Jeffrey's words, "the best dressed creatures of the night come to play" and New York's freshest DIY design collectives party and seek inspiration for collections, draws on traditions in both London and New York's club scenes of the eighties and early nineties, but also nods to a longer tradition of queer gender blurring dressing as a personal and political act.

GLF was strongly influenced by both the international student movement and the counterculture, and the 1973 GLF pamphlet, The Rise and Fall of Gay Liberation Front, acknowledged that it received support "mainly from that section of the gay population that had already been touched, to some extent at least, by either the 'new left,' or the counterculture."2 The GLF advocated "coming out" and the belief that "gay is good," with the GLF manifesto acknowledged and urged the rejection of "masculine" and "feminine" societal roles by gay people. ${ }^{3}$ This was revealed through clothing choices as an important indicator of this new visible gay identity. At first, GLF members' dress choices centered on hippie and countercultural dress styles. Bette Bourne, a founder of Radical drag performance 
troupe Bloolips, recalled that the first time he went to a GLF meeting he was wearing a suit but "soon realised it was not the scene" and the next meeting he wore "green velvet flared bottoms, T-shirt and a huge Afghan coat. My hair got longer and I had a beard like Che Guevara."4

Some GLF members felt that there should be a move away from the hard-edged definitions of gendered dress, and that conflicting signals could be used to challenge and confuse heterosexual society. "We began to realise that there were ways of using drag," recalled Michael James, "It's a way of giving up the power of the male role. We were holding the mirror up to man, showing that we rejected what maleness stood for." ${ }^{\text {Rejecting former }}$ drag or cross-dressing practices that aped iconic film stars or allowed wearers to "pass" as the opposite sex, "radical drag queens" took the extreme stereotypes of both male and female dress, combining feminine dresses and full make-up with workmen's boots, beards, and moustaches. Interviewed for Square Peg magazine in 1988, GLF member John Lloyd recalled that "for many people [radical drag queens] were the most intimidating members of GLF, a sort of moral 'Red Guard' of that period. They would sit at meetings, knitting away, in their 50s drag, looking terribly wonderful and being terribly threatening in case anyone put their foot wrong, which is what people did all the time." ${ }^{\prime 6}$ Drag historian Roger Baker has noted the effect that extreme forms of drag have on viewers manifesting as "the angry outrage of the person who finds his signals have been confused."

For GLF member Michael Brown genderfuck had a particularly performative element as he wore his "long beard tied up in plaits with pink ribbons and lips cut out from bright red acetate" with women's blouses and men's tight trousers to both socialize in and participating in street theatre forms of gay rights protests. ${ }^{8}$ Street theatre and new "queer" theatre groups such as Bloolips used their appearance and performances to critique stereotypes so they were "not so much imitations of women as creatures betwixt and between sexual roles, free from 
social rules." ${ }^{\prime 9}$ Educator and activist Benjamin Shepard has applied Roger Caillos's definition of play to queer activist performances, such as dress practices of radical drag, as a form of direct action that makes queer politics visible in public and to nonqueer audiences. ${ }^{10}$

Radical drag in London in the 1970s became a more overtly political form of drag when those who lived in the GLF communes wore it as everyday dress. In October 1972, a demonstration took place at The Champion pub in Notting Hill, London, over its policy on gay attendances and a number of GLF members were arrested. Not believing in changing their lifestyle or dress choices for anyone, the defendants turned up at court in drag. The trial was covered in Lunch, the journal of the far more conservative gay rights group, Campaign for Homosexual Equality: "Richard Chappell wore an ankle-length black satin dress with matching pill-box hat and net veil; Douglas MacDougall (of the same address) wore a pink polka-dot dress and green glitter round the eyes, while Peter [Bette] Bourne (actor) wore, to great effect, a red-patterned velvet dress." 11

The gay liberation movement of the 1960s and early 1970s fundamentally altered forms of gay life, in particular in London, but also in other large Western urban areas, and due to the performative activities and questioning of gendered appearances by radical drag participants, subsequently styles of GLBTQ* dress. Elements of the Genderfuck style of radical drag queens could be seen in the early 1970s through the glam rock styling of bisexual pop stars like David Bowie and March Bolan and their fans where elements of irony and camp reflected an apparent rejection of reality and escape from immediate concerns of the day.

Contemporary forms of drag and gender play in dress have used both the nightclub and the street as sites for expression and offered what Leila Rupp and Verta Taylor have termed "goals and strategies for challenging dominant constructions of masculinity [and] femininity,"12 echoing John Babuscio's 1975 reflection in Gay News newspaper that: "The 
gay movement [has] done much to break down the rigid boundary line separating masculinity from femininity." 13

This breaking down of barriers between masculine and feminine has been seen recent in contemporary fashion, designed not just by young club inspired designers like Jeffrey but by more established designers. Prada and Gucci both played with ideas of gender in their autumn/winter 2015 menswear shows, with the latter showing a collection that included pussy bow tied "blouses" in bright red and soft flesh pink alongside gilded red lace tops. London based designer J. W. Anderson included short skirts, fitted mini-dresses and shorts with exaggerated "frills" in his autumn/winter 2013 menswear collection. In a contemporary play on the ways in which 1970s radical drag queens juxtaposed gendered signifiers of feminine dresses and make-up with male secondary sexual characterizes such as beards, Walter Van Beirendonck, known for his provocative explorations of gender and traditional dress codes, designed green foam "beards" covered in fake foliage for his spring/summer 2009 "Explicit" collection.

In this way, the traditional gendered divisions in fashion collections have been challenged, reflecting a growing concern round the validity of the binary division of gender and the emergence of new identities and styles of dress based on androgyny, gender neutrality, and trans positioning. Although the gender play club costumes and fashion designs of Jeffrey and his New York counterparts are not as overtly political as the genderfuck strategies adopted by the radical drag queens of the 1970s, they still contribute to a personal and political consideration of queer sartorial choices.

\section{Notes}

\footnotetext{
${ }^{1}$ A film commissioned and made by $i-D$ magazine, https://www.youtube.com/watch?v=aVBYIGyj940 (accessed March 19, 2017).
} 
${ }^{2}$ David Fernbach, The Rise and Fall of Gay Liberation Front (London: Gay Culture Pamphlet, 1973), n.p.

${ }^{3}$ Gay Liberation Front Manifesto, reprinted in Lisa Power No Bath but Plenty of Bubbles: An Oral History of the Gay Liberation Front, 1970-1974 (London: Cassell, 1995), 325.

${ }^{4}$ Bette Bourne interview by Emma Hindley for Hall Carpenter Oral History Project, July 3, 1994, voice recording held at National Sound Archive at British Library, London.

${ }^{5}$ Quoted in Kris Kirk and Ed Heath, Men in Frocks (London: GMP, 1984), 104.

${ }^{6}$ Quoted in Keith Birch and Martin King, “The Nancy Revolution,” Square Peg no. 20 (1988), 31.

${ }^{7}$ Roger Baker, Drag (London: Cassell, 1994), 104.

${ }^{8}$ Michael Brown, interviewed by author, June 24, 2011, voice recording.

${ }^{9}$ Sally Banes, Subversive Expectations: Performance Art and Paratheter in New York, 197685 (Ann Arbor: University of Michigan Press, 1988), 108.

${ }^{10}$ Benjamin Shepard, Queer Political Performance and Protest (New York: Routledge, 2010).

${ }^{11}$ Bob Sturgess, Lunch, October 1972 in Lisa Power No Bath but Plenty of Bubbles: An Oral History of the Gay Liberation Front, 1970-1974 (London: Cassell, 1995), 269.

${ }^{12}$ Leila J. Rupp and Verta Taylor, Drag Queens at the 801 Cabaret (Chicago: University of Chicago Press, 2003), 218.

${ }^{13}$ Jack Babuscio, quoted in A Queer Reader, ed. Patrick Higgins (London: Fourth Estate, 1993), 207. (Original work published 1975) 